\title{
A Comparative Study of Intra Articular Platelet Rich Plasma and Steroid Injection in Patients with Osteoarthritis Knee
}

Badrunnesa Ahmed ${ }^{1 *}$, Md. Shafiqul Alam², Mohammad Tariqul Islam ${ }^{3}$, Syed Mozaffar Ahmed ${ }^{4}$, Taslim Uddin ${ }^{5}$, Md. Jahidul Islam ${ }^{6}$, Moshiur Rahman Khasru ${ }^{7}$

\footnotetext{
${ }^{1}$ Associate Professor, Department of Physical Medicine and Rehabilitation, Bangabandhu Sheikh Mujib Medical University, Dhaka, Bangladesh ${ }^{2}$ Brig. Gen.\& Professor, Depertment of Orthopaedics, Armed Forces Medical College, Dhaka Cantonment, Dhaka, Bangladesh

${ }^{3}$ Associate Professor, Department of Physical Medicine and Rehabilitation, Bangabandhu Sheikh Mujib Medical University, Dhaka, Bangladesh

${ }^{4}$ Professor, Department of Physical Medicine and Rehabilitation, Bangabandhu Sheikh Mujib Medical University, Dhaka, Bangladesh

${ }^{5}$ Professor, Department of Physical Medicine and Rehabilitation, Bangabandhu Sheikh Mujib Medical University, Dhaka, Bangladesh

${ }^{6}$ Professor, Dhaka Medical College, Dhaka, Bangladesh

${ }^{7}$ Associate Professor, Department of Physical Medicine and Rehabilitation, Bangabandhu Sheikh Mujib Medical University, Dhaka, Bangladesh
}

DOI: $10.36347 /$ sjams.2020.v08i10.031

| Received: 25.09.2020 | Accepted: 09.10.2020 | Published: 26.10.2020

*Corresponding author: Dr. Badrunnesa Ahmed

Introduction: Osteoarthritis (OA) knee is the most prevalent degenerative joint disease in the relatively elderly population. It is a leading cause of pain and disability in most countries worldwide. Aim of the study: To determine the effects of PRP in patients with OA knee. Material \& Methods: A total 60 patients with OA knee were selected irrespective of sexes seeking treatment in the department of Physical Medicine and Rehabilitation, BSMMU, Dhaka and also referred from various outpatient departments of BSMMU and also general practitioners outside the hospital. The diagnosis of OA knee was confirmed by history, clinical examination, laboratory and radiological findings. They were divided into two group from radiological grading (Kellgren-Lawrence grade-I-III).In group-A patients were given intraarticur steroid, exercise and ADL instructions and group-B were treated with Intraarticur PRP, exercise and ADL instruction. All the patient availed 6 follow up at two week interval and two injection were given at 1 st and 7 th week. In every follow up patients were assessed by Visual analogue scale (VAS) and WOMAC score. All data were analyzed statistically by using the SPSS (version-21) for windows. Both paired and unpaired Student's ' $t$ ' test and Chisquired test was done as required, to see the level of significance. The results were expressed as mean standard deviation (SD) and $\mathrm{p}<0.05$ was considered as the level of significance. Results: In both groups, majority of the participants had osteoarthritis in right knee joint. There is no statistical significance regarding knee involvement between two groups as the p-value is not significant. Table-4 showed the radiological grading of two groups. In both the groups most of the patients were enrolled in grade - II $(>50 \%)$. There is no statistical significance between the two groups. In comparison between two groups, it was found that there was no significant difference in improvement up to W1 to W9 scores, but difference of improvement was found in Group A than Group B at $11^{\text {th }}$ week. $(p=0.004)$. There was significant improvement in Group A. In respect to time improvement was started to occur in pretreatment $\mathrm{W} 1$ (just before $1^{\text {st }}$ Intervention) score Vs W3 score $15.8 \pm 0.65 \mathrm{Vs} 12.6 \pm 0.85$ respectively $(\mathrm{p}=0.003$ ). W3 score Vs W5 score was $12.6 \pm 0.85$ Vs $11.65 \pm 0.70(\mathrm{p}=0.084)$. W7 (just before $2^{\text {nd }}$ Intervention) score Vs W9 score $10.54 \pm 0.74$ Vs $5.35 \pm 0.57(\mathrm{p}=0.004)$. W9 score Vs W11 score was $-5.35 \pm 0.57$ Vs $2.15 \pm 0.30(\mathrm{p}=0.005)$. Whereas, in Group B, in respect to time improvement was started to occur in pretreatment W1 (just before $1^{\text {st }}$ Intervention) score Vs W3 score $16.65 \pm 0.48$ Vs $12.42 \pm .57(\mathrm{p}=0.001)$. Then W3 score Vs W5 score was12.42 \pm .57 Vs $11.38 \pm 0.49(\mathrm{p}=0.664)$. Then W7 (just before $2^{\text {nd }}$ Intervention) score Vs W9 score $9.46 \pm 0.58$ Vs $7.89 \pm 0.85(\mathrm{p}=0.050)$. Then W9 score Vs W11 score was $7.89 \pm 0.85 \mathrm{Vs} 5.65 \pm 0.76$ ( $\mathrm{p}=0.527$ ). Conclusion: The results from this study showed that intra articular injection of Platelet rich plasma administered to patients with OA knee had significant effects in pain reduction and functional improvement. Although both treatments offered significant effectiveness but PRP injections provided sustain pain reduction and improve physical function. Both treatment was well tolerated.

Keywords: Osteoarthritis (OA), Knee, Degenerative Joint Disease, Intra Articular Injection.

Copyright $\odot 2020$ The Author(s): This is an open-access article distributed under the terms of the Creative Commons Attribution 4.0 International License (CC BY-NC 4.0) which permits unrestricted use, distribution, and reproduction in any medium for non-commercial use provided the original author and source are credited. 


\section{INTRODUCTION}

Osteoarthritis (OA) knee is the most prevalent degenerative joint disease in the relatively elderly population [1]. It is a leading cause of pain and disability in most countries worldwide. Osteoarthritis (OA) knee is a degenerative joint disease characterized by biochemical and biomechanical alterations of articular cartilage, which is very common in the elderly population [2]. It is the most common cause of chronic pain and the loss of mobility, which can undermine overall health and quality of life of the affected patients $[3,4]$. The knee joint is the most frequently affected of all joints, and OA knee is one of the leading causes of global disability [5]. Radiographic evidence of OA knee is present in approximately $30 \%$ of men and more in women over the age of 65 [6], and in 2010, the global age-standardized prevalence of knee OA was 3.8\% [5]. The incidence of OA knee is increasing as a result of increasing obesity an ageing population6. It is the most prevalent form of arthritis and it is principle cause of disability in the elderly [6]. In United states 27 million adults (more than $10 \%$ of the U.S adult population) have been suffering from lineal OA and it is the fourth most common cause of hospitalization. It has been estimated that the percentage of people age 65 years and over in Asia will be more than double in the next two decades, from $6.8 \%$ in 2008 to $16.2 \% 2040$ [7]. Prevalence of osteoarthritis knee is $7.5 \%$ rural, $9.2 \%$ urban slum, $10.6 \%$ urban affluent community in Bangladesh perspective [8]. It is estimated that during the period 2008-2040, the proportion of people aged 65 years will increase by $261 \%$ in Bangladesh [8]. Patients with knee osteoarthritis is tend to increase their physical limitations, pain and functional restriction with disease progression. Thus these individuals suffer from progressive increase impact on their activities of daily living, which leads to losses in labor relation, leisure, social life and sleeping quality, leading also to important decrease in quality of life [9]. Available treatments for OA can be classified into three groups: drug, nondrug/nonsurgical (eg, physical and rehabilitation therapy, occupational therapy, massage, exercise) which are the primary line of treatment and surgical therapies. The sequence of treatment application begins with drug therapies and ends with surgical therapies [5, 6]. Corticosteroid and hyaluronic acid injections are the most commonly used agents for intra articular treatment. Intra articular steroid injections in knee OA are also among the recommendations of "Osteoarthritis Research Society International 2014" and "American College of Rheumatology (ACR) 2012" guidelines $[10,11]$. The disadvantage of corticosteroid injections is its short duration of benefit [12]. Hyaluronic acid's natural form can be found in healthy joint fluid and studies that demonstrate superiority over corticosteroid injections are available; however, an upto-date meta-analysis has emphasized clinical ineffectiveness and increased risk of serious side effects [13]. The role of complex regulation of growth factors is important to protect normal tissue structure and repair the tissue damage. In last few years, growth factor applications to damaged tissues have become a popular treatment option. Platelet rich plasma (PRP) contains four-five times more platelet concentration than normal blood and has more intense amounts of growth factor [14]. These growth factor [ie, platelet-derived growth factor (PDGF)] that increases the production of stem cells. This characteristic has made platelets attractive in OA treatment. Platelet rich plasma is a concentrate of platelets derived from the patient's own blood. It is a simple, low-cost and minimally invasive method for obtaining autologous growth factors [14]. Platelets in PRP contain growth factors and build up reparative process [15]. Currently, available drugs including analgesics, non -steroidal anti-inflammatory drugs (NSAIDs), glucosamine, chondroitin sulphate, and hyaluronic acid (HA), were applied for the treatment of OA knee to release pain and inflammation, and to improve knee function and quality of life [16]. Unfortunately, none of managements above can halt OA progression and reverse any existing damage. Biological therapies for focal knee osteoarthritis, such as platelet-rich plasma, have been proposed to improve clinical and structural outcomes by delivering a high concentration of growth factors that mediate healing and remodeling $[17,18]$. There are studies in the literature that include PRP-PRP, PRP-placebo, and PRP-hyaluronic acid comparisons; however, studies comparing corticosteroid-PRP injections in knee OA are significantly fewer 9].

\section{OBJECTIVES}

a) General Objective

- To determine the effects of PRP in patients with OA knee

\section{b) Specific Objectives}

- To determine the beneficial effects of PRP treatment in OA knee patients.

- To determine if there any untoward effect or not.

- To compare effect of PRP treatment with other intervention

\section{Methodology and Materials}

A total 60 patients with OA knee were selected irrespective of sexes seeking treatment in the department of Physical Medicine and Rehabilitation, BSMMU, Dhaka and also referred from various outpatient departments of BSMMU and also general practitioners outside the hospital. The diagnosis of OA knee was confirmed by history, clinical examination, laboratory and radiological findings. They were divided into two group from radiological grading (KellgrenLawrence grade-I-III).In group-A patients were given intraarticur steroid, exercise and ADL instructions and group-B were treated with Intraarticur PRP, exercise and ADL instruction. All the patient availed 6 follow up at two week interval and two injection were given at $1 \mathrm{st}$ 
and 7 th week. In every follow up patients were assessed by Visual analogue scale (VAS) and WOMAC score. All data were analyzed statistically by using the SPSS (version-21) for windows. Both paired and unpaired Student's ' $t$ ' test and Chi-squired test was done as required, to see the level of significance. The results were expressed as mean standard deviation (SD) and $\mathrm{p}<0.05$ was considered as the level of significance. In this study after recruitment of the subjects, the nature of the study were described thoroughly to the patients and the informed consent of the patients were taken.

\section{RESULTS}

A total of 60 patients were included in this study. In each group there were 30 patients. In group-A there were $12(40 \%)$ male and $18(60 \%)$ of female patients. In Group-B $13(43.33 \%)$ male and $17((56.67 \%)$ female, $\mathrm{p}$-value is more than 0.05 so there is no statistical significance of male and female ratio between the two groups. Male and female ratio was $1: 1.4$. The mean age of the patient in Group A was $52.53 \pm 8.34$ years whereas, in Group B 54.67 \pm 2.80 years, the mean height of the patient in Group A was $158.53 \pm 6.29 \mathrm{~cm}$ and in Group B $160.80 \pm 7.69 \mathrm{~cm}$, the mean weight of the patient in Group A was $68 \pm 7.71 \mathrm{~kg}$ and in Group B $67.60 \pm 10.50 \mathrm{~kg}$, BMI of patients in Group A was $26.91 \pm 1.23 \mathrm{~kg} / \mathrm{m} 2$ and in Group B was $25.99 \pm 2.20 \mathrm{~kg} / \mathrm{m} 2$ (Table-2). Regarding occupation of the patients, most of the patients in Group-A, were house wives 11(36.66\%), businessman 7(23.33\%), service holder $6(20 \%)$, day labour $4(13.33 \%)$ and others $2(6.68 \%)$. In Group-B most of the patients were housewives $12(40 \%)$, then service holders 7(23.33\%), Businessman 5(16.66\%), day labour 5(16.66\%) and others $1(3.35 \%)$. Regarding socio-economic condition of the patients out of 60 patients $36(60 \%)$ patients were from middle class, rich $17(28.33 \%)$, poor $7(11.67 \%)$. Table-3 shows the knee involvement of the two groups. In both groups, majority of the participants had osteoarthritis in right knee joint. There is no statistical significance regarding knee involvement between two groups as the p-value is not significant. Table- 4 showed the radiological grading of two groups. In both the groups most of the patients were enrolled in grade -II $(>50 \%)$.There is no statistical significance between the two groups. In comparison between two groups, it was found that there was no significant difference in improvement up to $\mathrm{W} 1$ to $\mathrm{W} 9$ scores, but difference of improvement was found in Group A than Group B at $11^{\text {th }}$ week. $(p=0.004)$. There was significant improvement in Group A. In respect to time improvement was started to occur in pretreatment W1 (just before $1^{\text {st }}$ Intervention) score Vs W3 score 15.8 \pm 0.65 Vs $12.6 \pm 0.85$ respectively $(p=0.003)$. Then $\mathrm{W} 3$ score Vs W5 score was $12.6 \pm 0.85$ Vs $11.65 \pm 0.70$ respectively $(\mathrm{p}=0.084)$. Then $\mathrm{W} 7$ (just before $2^{\text {nd }}$ Intervention) score Vs W9 score $10.54 \pm 0.74$ Vs 5.35 0.57 respectively $(\mathrm{p}=0.004)$. Then W9 score Vs W11$5.35 \pm 0.57$ score was Vs $2.15 \pm 0.30$ respectively $(\mathrm{p}=0.005)$. This indicates that intra articular platelet rich plasma is effective in OA knee. Whereas, in Group B, in respect to time improvement was started to occur in pretreatment W1 (just before $1^{\text {st }}$ Intervention) score Vs W3 score $16.65 \pm 0.48$ Vs $12.42 \pm .57$ respectively ( $\mathrm{p}=$ $0.001)$. Then W3 score Vs W5 score was $12.42 \pm .57 \mathrm{Vs}$ $11.38 \pm 0.49$ respectively $(\mathrm{p}=0.664)$. Then $\mathrm{W} 7$ (just before $2^{\text {nd }}$ Intervention) score Vs W9 score $9.46 \pm 0.58$ Vs $7.89 \pm 0.85$ respectively $(\mathrm{p}=0.050)$. Then $\mathrm{W} 9$ score Vs W11 score was $7.89 \pm 0.85 \mathrm{Vs} \quad 5.65 \pm 0.76$ respectively $(\mathrm{p}=0.527)$. The difference of improvement increases day by day up to $9^{\text {th }}$ week but at the end of treatment $11^{\text {th }}$ week it was not statistically significant. Treatment response of Group A Vs Group B in different weeks according to Pain subscale score of WOMAC in comparison between two groups, it was found that there was no significant difference in improvement up to $\mathrm{Wl}$ to W9 scores, but difference of improvement was found in Group A than Group B at $11^{\text {th }}$ were significant $(\mathrm{p}=.005)$. Treatment response of Group A Vs Group B in different weeks according to Pain subscale score of WOMAC in comparison between two groups, it was found that there was no significant difference in improvement up to $\mathrm{Wl}$ to $\mathrm{W} 11$ scores. Treatment response of Group A Vs Group B in different weeks according to Physical function subscale score of WOMAC in comparison between two groups, it was found that there was no significant difference in improvement up to $\mathrm{Wl}$ to $\mathrm{W} 11$ scores. Treatment response of Group A Vs Group B in different weeks according to total score of WOMAC In comparison between two groups, it was found that there was no significant difference in improvement up to W1 to W9 scores, but difference of improvement was found In Group A than Group B at $11^{\text {th }}$ were significant $(\mathrm{p}=<$ 0001).

Table-1: Sex distribution between the two groups

\begin{tabular}{|l|l|c|c|}
\hline Sex & GROUP-A & GROUP-B & P-value \\
\hline Male & $12(40 \%)$ & $13(43.33 \%)$ & 0.793 \\
\hline Female & $18(60 \%)$ & $17(56.67 \%)$ & \\
\hline
\end{tabular}

Table-2: Distribution of baseline characteristic of the patients.

\begin{tabular}{|l|l|l|}
\hline \multirow{2}{*}{ Attribute } & \multicolumn{2}{|l|}{ Mean \pm SD } \\
\cline { 2 - 3 } & Group A & Group B \\
\hline Age & $52.53 \pm 8.34$ & $54.67 \pm 2.80$ \\
\hline Height & $158.53 \pm 6.29$ & $160.80 \pm 7.69$ \\
\hline Weight & $68 \pm 7.71$ & $67.60 \pm 10.50$ \\
\hline BMI & $26.91 \pm 1.23$ & $25.99 \pm 2.20$ \\
\hline
\end{tabular}


Table-3: Comparison of knee involvement between two groups

\begin{tabular}{|l|l|l|l|}
\hline Knee involvement & Group-A(n=30) & Group-B(n=30) & p-value \\
\hline right & $15(50 \%)$ & $13(43.33 \%)$ & 0.850 \\
\hline Left & $12(40 \%)$ & $13(43.33 \%)$ & \\
\hline Both & $3(10 \%)$ & $4(13.34 \%)$ & \\
\hline
\end{tabular}

Table-4: Comparison of radiological grading between the two groups.

\begin{tabular}{|l|l|l|l|}
\hline Radiological grading & Group-A(n=30) & Group-B(n=30) & p-value \\
\hline Grade-I & $11(36.67 \%)$ & $12(40.01 \%)$ & 0.964 \\
\hline Grade-II & $17(56.67 \%)$ & $16(53.33 \%)$ & \\
\hline Grade-III & $2(6.66 \%)$ & $2(6.66 \%)$ & \\
\hline
\end{tabular}

Table-5: Treatment response of Group A \& Group B in relation to weeks according to VAS

\begin{tabular}{|c|c|c|c|c|}
\hline \multirow[t]{2}{*}{ Time-point score } & \multicolumn{2}{|c|}{ Group A $(n=28)$} & \multicolumn{2}{|c|}{ Group B $(n=29)$} \\
\hline & Mean \pm SD & p-Value & Mean \pm SD & p-Value \\
\hline $\mathrm{W} 1$ (1 $^{\text {st }}$ Intervention) Vs W3 & $\begin{array}{l}5.52 \pm 1.123 \mathrm{Vs} \\
4.14 \pm 1.740\end{array}$ & 0.00086 & $\begin{array}{l}6.15 \pm 1.084 \\
\text { Vs } 1.15 \pm 1.223\end{array}$ & $<.0001$ \\
\hline W3 Vs W5 & $\begin{array}{l}4.14 \pm 1.740 \\
\text { Vs } 1.81 \pm 1.401\end{array}$ & 0.000 & $\begin{array}{l}1.15 \pm 1.223 \\
\text { Vs } 1.27 \pm 1.343\end{array}$ & 0.723 \\
\hline $\begin{array}{l}\text { W5 Vs W7 } \\
\left(2^{\text {nd }} \text { Intervention }\right)\end{array}$ & $\begin{array}{l}1.81 \pm 1.401 \\
\text { Vs } 1.29 \pm 1.231\end{array}$ & 0.145 & $\begin{array}{l}1.27 \pm 1.343 \\
\text { Vs } 2.19 \pm 1.167\end{array}$ & 0.07 \\
\hline W7 Vs W9 & $\begin{array}{l}1.29 \pm 1.231 \\
\text { Vs } 1.33 \pm 0.483\end{array}$ & 0.087 & $\begin{array}{l}2.19 \pm 1.167 \\
\text { Vs } 0.46 \pm 0.859\end{array}$ & 0.000 \\
\hline W9 Vs W11 & $\begin{array}{l}0.33 \pm 0.483 \\
\text { Vs } 0.10 \pm 0.301 \\
\end{array}$ & 0.000 & $\begin{array}{l}0.46 \pm 0.859 \\
\text { Vs } 1.86 \pm 0.491\end{array}$ & 0.372 \\
\hline
\end{tabular}

Table-6: Treatment response of Group A Vs Group B in different weeks according to VAS

\begin{tabular}{|l|l|l|l|l|l|l|}
\hline Group & $\begin{array}{l}\text { W1 (1 } \\
\text { Intervention) }\end{array}$ & W3 & W5 & $\begin{array}{l}\text { W7 (2 } \\
\text { Intervention })\end{array}$ & W9 & W11 \\
\hline $\begin{array}{l}\text { Group A (n=15) Vs Group } \\
\text { B (n=15) Mean } \pm \text { SD) }\end{array}$ & $5.52 \pm 1.123$ & $4.14 \pm 1.740$ & $1.81 \pm 1.401$ & $1.29 \pm 1.231$ & $0.33 \pm 0.483$ & $00.10 \pm 0.301$ \\
& Vs $6.15 \pm 1.084$ & Vs $1.15 \pm 1.223$ & $\begin{array}{l}\text { Vs } \\
\text { Vs } 2.19 \pm 1.167\end{array}$ & $\begin{array}{l}\text { Vs } \\
0.46 \pm 0.859\end{array}$ & $1.86 \pm 0.491$ \\
\hline P-value & & 0.083 & 0.2904 & 0.493 & 0.6134 & $<0.0001$ \\
\hline $\begin{array}{l}\text { The results are expressed in mean } \pm \text { standard deviation (SD). } \\
\text { n= Number of the patients participated in the clinical trial. }\end{array}$ \\
W= Week
\end{tabular}

Table-7: Treatment response of Group A \& Group B in response to weeks according to Pain Subscale Score

\begin{tabular}{|l|l|l|l|l|}
\hline \multirow{2}{*}{ Time-point score } & Group-A & Group-B & \\
\cline { 2 - 5 } & Mean \pm SD & p-Value & Mean \pm SD & p-Value \\
\hline W1 (1 $1^{\text {st }}$ Intervention/Baseline) Vs W3 & $15.8 \pm 0.65$ & 0.000 & $16.65 \pm 0.48$ & 0.001 \\
& Vs & & Vs & \\
& $12.6 \pm 0.85$ & & $12.42 \pm .57$ & \\
\hline W3 Vs W5 & $12.6 \pm 0.85$ & 0.084 & $12.42 \pm .578$ & 0.664 \\
& Vs & & Vs & \\
& $11.65 \pm 0.70$ & & $11.38 \pm 0.49$ & \\
\hline W5 Vs W7 & $11.65 \pm 0.70$ & 0.332 & $11.38 \pm 0.49$ & 0.334 \\
$\left(2^{\text {nd }}\right.$ Intervention) & Vs & & Vs & \\
& $10.54 \pm 0.74$ & & $9.46 \pm 0.58$ & \\
\hline W7 (2 ${ }^{\text {nd }}$ Intervention) Vs W9 & $10.54 \pm 0.74$ & 0.004 & $9.46 \pm 0.58$ & 0.050 \\
& Vs & & Vs & \\
& $5.35 \pm 0.57$ & & $7.89 \pm 0.85$ & \\
\hline W9 Vs W11 & $5.35 \pm 0.57$ & 0.005 & $7.89 \pm 0.85$ & 0.527 \\
& Vs & & Vs & \\
& $2.15 \pm 0.30$ & & $5.65 \pm 0.76$ & \\
\hline The results are expressed in mean \pm standard deviation (SD). & & \\
n= Number of the patients participated in the clinical trial. & & \\
According to pain subscale score & & & \\
\hline
\end{tabular}


Table-8: Treatment response of Group A \& Group B in relation to weeks according to Pain subscale score of WOMAC

\begin{tabular}{|c|c|c|c|c|c|c|}
\hline Group & $\begin{array}{l}\text { W1 } \\
\left(1^{\text {st }}\right. \\
\text { Intervention }) \\
\end{array}$ & W3 & W5 & $\begin{array}{l}\text { W7 } \\
\left(2^{\text {nd }}\right. \\
\text { Intervention }) \\
\end{array}$ & W9 & W11 \\
\hline $\begin{array}{l}\text { Group A }(n=15) \text { Vs Group B }(n=15) \\
\text { Mean } \pm \text { SD })\end{array}$ & $\begin{array}{l}15 . .8 \pm 0.65 \\
\text { Vs } \\
16.65 \pm 0.0 .4\end{array}$ & $\begin{array}{l}12.6 \pm 0.85 \\
\text { Vs } \\
12.42 \pm 0.57\end{array}$ & $\begin{array}{l}11.65 \pm 0.70 \\
\text { Vs } \\
11.38 \pm 0.49\end{array}$ & $\begin{array}{l}10.54 \pm 0.74 \\
\text { Vs } \\
9.46 \pm 0.58\end{array}$ & $\begin{array}{l}5.35 \pm 0.57 \\
\text { Vs } \\
7.89 \pm 0.85\end{array}$ & $\begin{array}{l}2.15 \pm 0 \\
.30 \\
\text { Vs } \\
5.65 \pm 0 \\
.76 \\
\end{array}$ \\
\hline P-value & 0.180 & 0.501 & 0.231 & 0.124 & 0.000 & 0.000 \\
\hline
\end{tabular}

Table-9: Treatment response of Group A \& Group B in relation to weeks according to Stiffness score of WOMAC

\begin{tabular}{|c|c|c|c|c|c|c|}
\hline Group & $\begin{array}{l}\text { W1 } \\
\left(1^{\text {st }}\right. \\
\text { Intervention })\end{array}$ & W3 & W5 & $\begin{array}{l}\text { W7 } \\
\left(2^{\text {nd }}\right. \\
\text { Intervention })\end{array}$ & W9 & W11 \\
\hline $\begin{array}{l}\text { Group A }(n=15) \text { Vs Group B }(n=15) \\
\text { Mean } \pm \text { SD })\end{array}$ & $\begin{array}{l}4.5 \pm 0.29 \\
\text { Vs } \\
5.24 \pm 0.0 .76\end{array}$ & $\begin{array}{l}3.35 \pm 0.78 \\
\text { Vs } \\
3.65 \pm 0.52\end{array}$ & $\begin{array}{l}3.54 \pm 0.82 \\
\text { Vs } \\
3.05 \pm 0.65\end{array}$ & $\begin{array}{l}3.56 \pm 0.37 \\
\text { Vs } \\
3.64 \pm 0.75\end{array}$ & $\begin{array}{l}2.0 \pm 0.43 \\
\text { Vs } \\
1.45 \pm 0.23\end{array}$ & $\begin{array}{l}1.10 \pm 0.54 \\
\text { Vs } \\
1.24 \pm 0.29\end{array}$ \\
\hline P-value & 0.1484 & 0.225 & 0.080 & 0.1237 & 0.00015 & 0.026 \\
\hline
\end{tabular}

The results are expressed in mean \pm standard deviation $(\mathrm{SD})$.

$\mathrm{n}=$ Number of the patients participated in the clinical trial.

$\mathrm{W}=$ Week

Table-10: Treatment response of Group A Vs Group B in different weeks according to stiffness subscale score

\begin{tabular}{|c|c|c|c|c|c|c|}
\hline Group & $\begin{array}{l}\text { W1 } \\
\left(1^{\text {st }}\right. \\
\text { Intervention })\end{array}$ & W3 & W5 & $\begin{array}{l}\text { W7 } \\
\left(2^{\text {nd }}\right. \\
\text { Intervention })\end{array}$ & W9 & W11 \\
\hline $\begin{array}{l}\text { Group A }(n=15) \text { Vs Group B } \\
(n=15) \text { Mean } \pm \text { SD })\end{array}$ & $\begin{array}{l}52.25 \pm 10.43 \\
\text { Vs } \\
52.93 \pm 11.69\end{array}$ & $\begin{array}{l}42.50 \pm 12.42 \\
\text { Vs } \\
38.20 \pm 11.46\end{array}$ & $\begin{array}{l}38.28 \pm 10.20 \\
\text { Vs } \\
38.05 \pm 11.54\end{array}$ & $\begin{array}{l}37.56 \pm 10.34 \\
\text { Vs } \\
36.64 \pm 9.43\end{array}$ & $\begin{array}{l}32.0 \pm 08.28 \\
\text { Vs } \\
32.45 \pm 5.43\end{array}$ & $\begin{array}{l}24 \pm 0.45 \\
V s \\
30 \pm 0.76\end{array}$ \\
\hline $\mathrm{P}$-value & 0.867 & 0.332 & 0.954 & 0.8009 & 0.0927 & $<0.0001$ \\
\hline
\end{tabular}

Table-11: Treatment response of Group A \& Group B in relation to weeks according to total score of WOMAC

\begin{tabular}{|c|c|c|c|c|c|c|}
\hline Group & $\begin{array}{l}\text { W1 } \\
\left(1^{\text {st }}\right. \\
\text { Intervention })\end{array}$ & W3 & W5 & $\begin{array}{l}\text { W7 } \\
\left(2^{\text {nd }}\right. \\
\text { Intervention })\end{array}$ & W9 & W11 \\
\hline $\begin{array}{l}\text { Group A }(n=15) \text { Vs Group B } \\
(n=15) \text { Mean } \pm \text { SD })\end{array}$ & $\begin{array}{l}72.55 \pm 11.37 \\
\text { Vs } \\
74.82 \pm 12.93\end{array}$ & $\begin{array}{l}58.45 \pm 14.48 \\
\text { Vs } \\
54.27 \pm 12.54\end{array}$ & $\begin{array}{l}53.47 \pm 11.72 \\
\text { Vs } \\
52.48 \pm 12.68\end{array}$ & $\begin{array}{l}51.66 \pm 11.58 \\
\text { Vs } \\
49.74 \pm 10.76\end{array}$ & $\begin{array}{l}39.35 \pm 9.28 \\
\text { Vs } \\
41.79 \pm 6.51\end{array}$ & $\begin{array}{l}28.25 \pm 0.29 \\
\text { Vs } \\
37.89 \pm 0.81\end{array}$ \\
\hline $\mathrm{P}$-value & 0.0653 & 0.3328 & 0.735 & 0.0643 & 0.0564 & $<0.0001$ \\
\hline
\end{tabular}

The results are expressed in mean \pm standard deviation (SD).

$\mathrm{n}=$ Number of the patients participated in the clinical trial.

$\mathrm{W}=$ Week

\section{DISCUSSION}

Osteoarthritis (OA) is estimated to be the fourth leading cause of disability [19]. Because of its chronic, painful and disabling character. In OA there is imbalanced homeostasis and destruction of the articular cartilage, in which pro-inflammatory cytokines are important catabolic regulators during OA cascade. PRP is natural concentrate of autologous growth factors from the blood. It allows in a simple, low cost a minimally invasive way to obtain a concentration of many growth factors [19]. The application of PRP to treat OA of the knee can be considered a relatively new therapeutic indication. In this study among 60 patients $35(58.33 \%)$ were female and $25(41.67 \%)$ were male. Male: female ratio was $1: 1.4$. Age is the risk factors mostly correlated with OA. In this study, the mean age of the respondents in group-A 52.53 \pm 8.34 and Group-B 54.67 \pm 2.80 (mean53.6 \pm 9.74 ). A study was conducted in Chittagong 
where the researchers also found that the mean age of OA knee patients was $53.73 \pm 11.35$ years [6]. Increased weight has major effect in enveloping OA knee mean BMI of the patients was $26.45 \pm 1.715 \mathrm{~kg} / \mathrm{m}^{2}$ that is overweight. Regarding occupation most patients were house wives $11(36.66 \%)$ then businessman $7(23.33 \%)$, service holder $6(20 \%)$, day labour $4(13.33 \%)$ and other $2(6.68 \%)$ in Group-A. In Group-B house wives $12(40 \%)$, then service holder $7(23.33 \%)$, businessman $5(16.66 \%)$ day labour $5(16.66 \%)$ and others $1(3.35 \%)$. Regarding socio economic condition $36(60 \%)$ patients were from middle class, rich $17(28.33 \%)$, poor $7(11.67 \%)$. For the assessment of pain, a visual analog scale was used. Meheux et al., [20] have mentioned that PRP injections could be administered in two-four weeks apart to patients with symptomatic knee OA between Kellgren-Lawrence grades 1 to 3 . In our study we gave PRP and intra articular steroid at 6 weeks' interval. The mean VAS score of the respondents was 5.52 in GroupA. The VAS score gradually decreased in W3, W5, W7, W9 and in W11, and in W11 the VAS score was 0.1. In Group-B at the beginning of treatment the mean VAS score was 6.15 then it also decreased gradually during the next follow ups. At the initial stage there was no significant difference between two groups regarding VAS score, but in W11 there was significant statistical differences regarding VAS score between two groups as the $\mathrm{p}$ value was 0.004 . In a comparative study between PRP and corticosteroid in OA knee VAS of PRP groups was lowered at second month than Intra articular corticosteroid group [21]. At the initial stage there was no statistical difference between two groups regarding pain, stiffness score and physical function. In Group-A, the pain, stiffness and physical function score gradually decreased in Week 3, Week 5, Week 7, Week 9 and week 11. Sampson and colleagues evaluated the effect of 3 monthly doses of PRP in 14 patients with OA knee refractory to conservative treatment. They observed linear improvement of VAS and knee injury OA outcome in $60 \%$ of patients at follow up [22]. Uslu Gavendi E et al., [23] reported improvement of all three subscales of WOMAC in intra articular PRP groups in comparison with steroid group, but in our study we got significant improvement in pain subscale score and physical function score more in PRP group than steroid group. There was no significant difference regarding stiffness subscale score between the two groups. Platelet rich plasma has been reported as a safe treatment with no serious complications. Minor side effects reported as a safe treatment with no serious complications. Minor side effects reported with repeated intra articular injections are pain, swelling and mil effusion that can last a few days. In our study, in Group-A (PRP group), 2 respondent developed localized pain and 1 respondent localized swelling around the joint. In Group-B there were no notifiable adverted effect seen. Platelet rich plasma may influence the overall joint homeostasis, reducing synovial membrane hyperplasia and modulating the cytokine level, thus leading to an improvement in the clinical outcome, even if only temporarily and without affecting the cartilage tissue structure and joint degenerative progression.

\section{LIMITATIONS OF THE STUDY}

This was a single centered study with comparatively small number of sample size. Follow up period was short, PRP was prepared in other department. We evaluated only clinical parameters by using the VAS and WOMAC scoring systems. Radiographic follow up investigation methods such as magnetic resonance imaging or Ultrasonography may be considered for evaluating cartilage regeneration (if any) in subsequent research, we could not do this because of the cost and ethical issues.

\section{CONCLUSION}

The results from this study showed that intra articular injection of Platelet rich plasma administered to patients with OA knee had significant effects in pain reduction and functional improvement. Although both treatments offered significant effectiveness but PRP injections provided sustain pain reduction and improve physical function. Both treatment was well tolerated. From this study it is suggested that intra articular injection of double dose PRP Injection in six weeks' interval in patients with OA knee within an appropriate care can provide adequate pain relief and significant functional improvement.

\section{RECOMMENDATIONS}

From this clinical trial, it can be recommended that intra articular PRP injection in patients with OA knee with an appropriate care provide adequate pain relief and significant functional improvement. Special attention should be given to reduce disability of the patients with knee OA. Furthermore, well designed Long term follow up, multicenter clinical trial is recommended to include to see the effect of PRP injection in patients with OA knee. It is also can be recommended that Physical Medicine \& Rehabilitation department of BSMMU should procure PRP preparation tools a kits for smooth delivery of the service.

Source of Funding: University Research Grant Commission, BSMMU, Dhaka, Bangladesh.

Conflict of Interest: None declared

\section{REFERENCES}

1. World Health Organization. World Health Report, Reducing Risks, Promoting Healthy life. Geneva. WHO, 2002.

2. Abate M, Verna S, Schiavone C, Di Gregorio P, Salini V. Efficacy and safety profile of a compound composed of platelet-rich plasma and hyaluronic acid in the treatment for knee 
osteoarthritis (preliminary results). Eur J OrthopSurg Traumatol. 2015; 25: 1321-1326.

3. Dieppe PA and Lohmander LS. Pathogenesis and management of pain in osteoarthritis. Lancet 2005; 365: 965-973.

4. Alshami AM. Knee osteoarthritis related pain: a narrative review of diagnosis and treatment. Int $\mathrm{J}$ Health Sci (Qassim). 2014; 8: 85-104.

5. Alvarez-Camino J, Vazquez-Delgado E, GayEscoda C. Use of autologous conditioned serum (Orthokine) for the treatment of the degenerative osteoarthritis of the temporomandibular joint. Review of the literature. Med Oral Patol Oral Cir Bucal. 2013; 18: e433-438.

6. Shakoor MA, Taslim MA, Ahmed MS, Hasan SA. Clinical profile of patients with Osteoarthritis of the knee: A study of 162 cases. Indian Journal of Physial Medicine and Rehabilitaion, 2009; 20(2):44-47.

7. Fansen M, Bridgett I, March I, Hoy, Penserga E, Brooks P. The Epidemiology of Osteoarthritis in Asia. International Journal of Rheumatic Diseases, 2011;14(2):113-21.

8. Haq SA, Divatchi F. Osteoarthritis of the knees in COPCORD world. International journal of Rheumatic diseases, 2011;14(2):122-29.

9. Sutbeyaz ST, Sezer N, Koseoglu BF, Ibrahimoglu $\mathrm{F}$, Tekin D. Influence of knee osteoarthritis on exercise capacity and quality of life in obese adults. Obesity. 2007 Aug;15(8):2071-6.

10. Hochberg MC, Altman RD, April KT, Benkhalti M, Guyatt G, McGowan J, Towheed T, Welch V, Wells G, Tugwell P. American College of Rheumatology 2012 recommendations for the use of nonpharmacologic and pharmacologic therapies in osteoarthritis of the hand, hip, and knee. Arthritis care \& research. 2012 Apr;64(4):465-74.

11. McAlindon TE, Bannuru RR, Sullivan MC, ArdenNK, Berenbaum F, Bierma-Zeinstra SM, et al. OARSIguidelines for the non-surgical management of kneeosteoarthritis. Osteoarthritis Cartilage. 2014; 22:363-88.

12. Bannuru RR, Natov NS, Obadan IE, Price LL, Schmid CH, McAlindon TE. Therapeutic trajectory ofhyaluronic acid versus corticosteroids in the treatmentof knee osteoarthritis: a systematic review and metaanalysis.Arthritis Rheum. 2009; 61:1704-11.

13. Rutjes AW, Jüni $\mathrm{P}$, da Costa BR, Trelle $\mathrm{S}$, Nüesch E, Reichenbach S. Visco supplementation for osteoarthritis of the knee: a systematic review and meta-analysis. Ann Intern Med. 2012; 157:180-91.
14. Filardo G, Kon E, Buda R, Timoncini A, Di Martino A, Cenacchi A, Fornasari PM, Giannini S, Marcacci M. Platelet-rich plasma intra-articular knee injections for the treatment of degenerative cartilage lesions and osteoarthritis. Knee Surgery, Sports Traumatology, Arthroscopy. 2011 Apr 1;19(4):528-35.

15. Nuki G. Osteoarthritis. In: Luqmani R, Robb J, Porter D, editors. Textbook of Orthopaedics, Trauma and Rheumatology. Chicago, IL: Mosby; 2008:193.

16. Handl M, Amler E, Braun K, Holzheu J, Trc T, Imhoff AB, Lytvynets A, Filova E, Kolarova H, Kotyk A, Martinek V. Positive effect of oral supplementation with glycose-amino glycans and antioxidants on the regeneration of osteochondral defects in the knee joint. Physiol Res. 2007; 56: 243-249.

17. Arnold W, Fullerton D, Holder S, May C. Viscosupplementation: managed care issues for osteoarthritis of the knee. J Manag Care Pharm. 2007;13: S3-19; quiz S20-S12. [PubMed]

18. Wang-Saegusa A, Cugat R, Ares O, Seijas R, Cuscó X, Garcia-Balletbó M. Infiltration of plasma rich in growth factors for osteoarthritis of the knee short-term effects on function and quality of life. Archives of orthopaedic and trauma surgery. 2011 Mar 1;131(3):311-7.

19. Arora N, Ramanayake T, Ren Y, Romanos GE. Platelet-rich plasma: a literature review. Implant Dent. 2009;18(4):303-10.

20. Filardo G, Kon E, Di Martino A, Di Matteo B, Merli ML, Cenacchi A, Fornasari PM, Marcacci M. Platelet-rich plasma vs hyaluronic acid to treat knee degenerative pathology: study design and preliminary results of a randomized controlled trial. BMC musculoskeletal disorders. 2012 Dec 1;13(1):229-36.

21. Meheux CJ, McCulloch PC, Lintner DM, Varner KE, Harris JD. Efficacy of Intra-articular PlateletRich Plasma Injections in Knee Osteoarthritis: A Systematic Review. Arthroscopy. 2016; 32:495505.

22. Sampson S, Ree M, Silvers H, Meng M. Injection of platelet rich plasma in patients with primary and secondary knee osteo arthritis: A pilot study. American Journal of Physical Medicine \& Rehabilitation. 2010; 89(12):961-969.

23. Oslu Guvandi E, Askin A, Govendi G, Kocyigit HC. Comparison of Efficiency between Corticosteroid and Platelet rich plasma injection Therapies in patients with knee osteo arthritis. Arch Rheumatol. 2018; 33(3):273-281. 